Justyna Kroczak

Instytut Filozoficzny

Uniwersytet Zielonogórski

http://dx.doi.org/10.18778/8088-249-2.16

\title{
MISTYCZNY ROZWÓJ CZŁOWIEKA NA PRZYKŁADZIE HEZYCHAZMU I SUFIZMU
}

Współegzystencja islamu i chrześcijaństwa trwa od VII w. wraz z zajęciem przez Arabów wschodnich prowincji Cesarstwa Bizantyjskiego (Syrii w 636 r.; Palestyny w 637 r.; Egiptu w 642 r.). Współczesny badacz Irfan Shahid pisze w związku z tym, że islamski kalifat, w sposób naturalny, stał się nowym kontekstem hellenistycznego dziedzictwa [Shahid 2007: 50]. I faktycznie, islam nie pozostał obojętny na spuściznę antyczną, szczególnie na filozofię grecką, jednak w stosunku do chrześcijaństwa, które od III w. stopniowo zaczęło dominować w świecie grecko-rzymskim był nastawiony wrogo. Chrześcijaństwo z kolei początkowo traktowało religię Mahometa jako niebezpieczną herezję, a nawet jako „zwiastun antychrysta” - tak było np. u św. Jana z Damaszku (675-749), który w dziele $O$ herezjach, określił islam mianem herezji izmaelitów i nawoływał do ich wyklęcia i wyrzeczenia się. Doszedł do takiego wniosku na podstawie analizy niektórych „pism” czyli sur mówiących o zakazie picia wina, stosunku do cudzych żon czy kamieniu znajdującym się w Kaabie [Jan z Damaszku 2011: 135-139]. Warto zauważyć, że krytyka Jana z Damaszku wynikała z lektury Koranu i jego dosłownej interpretacji oraz, być może, naturalnej w VIII w. wrogości do Saracenów. W bogatej literaturze bizantyjskiej nie brakuje również przykładów dzieł polemicznych wynikających z bezpośrednich konfrontacji z wyznawcami islamu, przykładami mogą być m.in. czternastowieczne prace św. Grzegorza Palamasa (1296-1357) oraz piętnastowieczne dzieło Dialog o religii chrześcijańskiej cesarza bizantyjskiego Manuela II Paleologa (1391-1425).

Filoteusz Kokkinos (1300-1379), autor biografii Palamasa, pisał, że jego mistrz dostał się do rocznej niewoli tureckiej w 1354 roku. Jan VI Kantakuzen i Jan V walczyli ze sobą w tym czasie o tron cesarski i chcieli wykorzystać do mediacji osobę Palamasa. W drodze do Konstantynopola statek, na którym podróżował Ojciec kościoła musiał zakotwiczyć w Calliopolis (Gallipoli), w porcie na morzu Marmara z powodu trzęsienia ziemi 2 marca 1354 r., właśnie wtedy został pochwycony przez Turków osmańskich. Wiemy, że w czasie niewoli Palamas przeprowadził trzy dysputy religijne w pałacu emira Orchana. Palamas negował w nich nie tylko dogmaty islamskie, ale także sposób bycia i zachowania Turków-muzułmanów, nazywając ich barbarzyńcami i ludźmi nieokrzesanymi. Czę- 
ściowo wynikało to ze złych warunków w jakich go przetrzymywano [Kokkinos 1865: col. 551B-656C; The lives of the pillars 1990: 325].

Trzej wymienieni autorzy: Jan z Damaszku, Grzegorz Palamas i Manuel II Paleolog w swych pracach odwoływali się do dogmatycznej strony teologii muzułmańskiej, co naturalnie nie mogło poskutkować jej entuzjastycznym przyjęciem. Jeśli jednak wziąć sferę mistyki, dialog międzyreligijny w kwestii kondycji i rozwoju człowieka oraz jego relacji do Boga staje się możliwy. Zwrócili na to uwagę sami sufi, którzy często w sposób niezwykle afirmujący odnosili się do postaci Jezusa. Hezychastyczni Ojcowie Kościoła z kolei, nie wypowiadali się na temat sufizmu, przynajmniej świadectwa historyczne o tym milczą. Wśród współczesnych badaczy religijności temat tożsamości hezychazmu i sufizmu nie jest nowy, szczególnie cenne są refleksje biskupa Cerkwi Prawosławnej metropolity Kallistosa (ur. 1934) i nieżyjącego już trapisty Thomasa Mertona (1915-1968). Ten pierwszy znany jest z popularyzacji modlitwy Jezusowej (serca bądź umysłu) i wskazywania na jej związki z muzułmańskim dhikr, drugi natomiast z poezji utrzymanej w duchu sufickim.

Mistyka jest jednym z możliwych wymiarów każdej religii, francuski teolog Włodzimierz Łosski (1903-1958) pisał nawet, że „każda teologia jest mistyczna, jeśli odsłania to, co dane w Objawieniu, bo sam Bóg jest niepoznawalny" [Łosski 2007: 15]. Można ją zatem zdefiniować jako pogłębioną świadomość symbolicznego znaczenia rzeczywistości materialnej [Tomkowski 2006: 6]. Taka definicja sugeruje, że mistyka dostępna jest dla nielicznych, charakteryzowałaby się więc elitaryzmem, czyli ezoteryzmem. Warto jednak zauważyć, że religie uniwersalistyczne takie jak chrześcijaństwo i islam dążą do bycia egalitarnymi, powszechnymi. Mistyka w odniesieniu do nich nie będzie zatem niczym w rodzaju „sekretnej doktryny”, będzie raczej głębią, „kwintesencją i najwyższą formą religii” [Gentili 1997: 50], która ma pozwolić dostrzec manifestacje boskich tajemnic, w założeniu dostępna jest wszystkim wiernym. Sergiusz Choruży, rosyjski badacz hezychazmu pisze, że: „z punktu widzenia nauki prawosławnej doświadczenie ascezy hezychastycznej jest doświadczeniem dążenia do Chrystusa i zjednoczenia z nim w Jego energiach, poprzez Ducha Świętego [...]. Odnalezienie tego doświadczenia jest celem [...] wszystkich chrześcijan” [Choruży 2014: 145]. Elitaryzm jest więc całkiem obcy hezychazmowi, natomiast w przypadku sufich rzecz nie jest do końca jasna. Niekiedy można spotkać się z opinią, że według sufich ich wiedza wykracza poza wiedzę innych wiernych i ludzi w ogóle [Chittick i in. 2012: 10]. Nie identyfikują się oni również z podziałem islamu na szyizm i sunnizm. W związku z tym sufizm będzie czymś innym niż oficjalna teologia islamska. Majid Fakhry, współczesny historyk filozofii muzułmańskiej podaje, że doktryna islamu nie zachęca do mistycznych poszukiwań i ascetyzmu, są tego przynajmniej trzy przyczyny: 1) idea absolutnej transcendencji Boga, co zniechęca do prób kontaktu z nim; 2) rytuały islamu są nieskomplikowane i dokładnie określone, w związku z czym trudno je w sposób dowolny interpretować; 
3) w islamie istnieje ścisły związek między doczesnością i światem duchowym oraz ich równoważnością natomiast mistycyzm postuluje coś całkiem odwrotnego [Fakhry 2004: 234-235]. Sami sufi wierzą, że tarika, tj. droga sufizmu, nastawiona na zgłębianie wewnętrznego wymiaru duchowości islamskiej, dopełnia szariat, stanowi do niego ezoteryczny komentarz. Nauka, którą propagują, zawarta jest zarówno w samym Koranie (3: 16-18), jak i w tradycji, która przekazuje, że Mahomet zobowiązywał wszystkich muzułmanów do szukania wiedzy. Przykładem myśliciela, który z powodzeniem łączył te dwa wymiary islamu był al-Ghazali (1058-1111). Al-Ghazali - z jednej strony krytyk filozofii, przede wszystkim systemów Platona i Arystotelesa, z drugiej wyraźnie inspirujący się metaforami platońskimi i neoplatońskimi oraz logiką Arystotelesa - położył intelektualny fundament pod sufizm, broniąc jednocześnie sunnickiej dogmatyki. Uważał, że sufizm pomaga człowiekowi moralnie wzbogacać się i doskonalić. Jednak suficki postulat ontologicznej jedności człowieka z Bogiem uznał za symbol a nie zadanie możliwe do wypełnienia.

Hezychazm, w odróżnieniu od sufizmu, ma status jasno określony, stanowi oficjalną naukę Kościoła Prawosławnego zatwierdzoną na Soborze Konstantynopolitańskim V w 1351 r. Uważa się nawet, że Triady, główna praca polemiczno-dogmatyczna Grzegorza Palamasa jest najważniejszym dziełem teologiczno-duchowym prawosławia.

Czasy życia Palamasa, tj. XIV w., to okres renesansu Paleologów, jednym z jego osiągnięć były rozkwit i usystematyzowanie tradycji hezychastycznej trwającej praktycznie nieprzerwanie od IV w. Pomimo tego, że nazywany „renesansem", uchodzi za okres schyłkowy. W 1453 r. sułtan osmański Mehmed II wkroczył do Hagii Sophii i tym symbolicznym gestem zajął Konstantynopol. Wtedy właśnie centrum kultury, teologii i filozofii prawosławnej przeniosło się na Ruś, która zaczęła pretendować do tego aby stać się Nowym Konstantynopolem i Trzecim Rzymem. W sposób naturalny tradycja hezychastyczna swoje przedłużenie znalazła zatem w państwie ruskim. Tutaj, w związku $\mathrm{z}$ wieściami o barbarzyństwie Turków osmańskich, a także własnych doświadczeń z czasów niewoli tataro-mongolskiej, wrogość do islamu przyjęła skrajną postać. Paweł z Aleppo (1627-1669), arabski duchowny prawosławny pisał w Opisie podróży Makarego, że nienawiść do języka tureckiego (który bardziej niż arabski asocjowano wtedy $\mathrm{z}$ islamem) była na Rusi ogromna. W $1655 \mathrm{r}$. miało miejsce spotkanie cara Aleksego I Romanowa z patriarchą antiocheńskim Makarym III (um. 1675). Makary nie władał językiem ruskim, mówił natomiast po turecku (jako, że Antiochia w tym czasie należała do Imperium Osmańskiego) i chciał, aby dragoman tłumaczył jego słowa z tureckiego, na wieść o tym Aleksy I miał wykrzyknąć: „Boże, chroń aby taki święty mąż skalał swoje usta i język tą nieczystą mową”. Na szczęście dla patriarchy, znał on również grekę i właśnie ten język posłużył w komunikacji [Opis podróży Makarego 1898: 21]. W wiekach późniejszych, szczególnie w XIX i XX, krytyka islamu jeszcze się zaostrzyła. Głównymi jej oponentami byli 
dostojnicy Cerkwi Prawosławnej, hezychaści: Ignacy Brianczaninow, Teofan Rekluz i Jan z Kronsztadu. Ten pierwszy nazywa Mahometa fałszywym prorokiem, a jego wyznawców ludźmi, którzy nie dostąpią zbawienia, ponieważ nie wierzą w Chrystusa - Bogoczłowieka. Islam stanowił według Ignacego Brianczaninowa formę pogaństwa [Бранчанинов 2007: 178-185]. Jednak i w tym wypadku mamy do czynienia albo z podejściem uprzedzonym albo odwołaniem do islamskich prawd wiary, a nie do mistyki.

Konkludując, z powyższego jasno wynika, że status obu tradycji duchowych jest różny, jednak lektura dzieł mistrzów hezychazmu i sufizmu, przede wszystkim Drabiny raju (Climaks tou paradeisou) Jana Klimaka, Triad w obronie świętych hezychastów (Hyper ton hieros hesyhadzonton) i Obrony szczegótowej (Apologia dieksodikotera) Palamasa, Homilii duchowych (Homilai pneumatikai) Pseudo-Makarego, Traktatu o mitości (Al-Futuhat al-makkiyya) Ibn Arabiego, Rymowanych dwuwierszy o głębokim, duchowym znaczeniu (Masnavi) Rumiego, Niszy światet (Mishkat al-Anwar) al-Ghazaliego, Ksiegi blasku (Kitab al-Luma) al-Sarraja jednoznacznie wskazuje na podobieństwa, przede wszystkim w kwestiach: rozumienia Boga i jego atrybutów, relacji między człowiekiem i Bogiem oraz metafizyki serca. W dalszej części rozdziału przejdę do charakterystyki wskazanych punktów.

Sufizm i hezychazm są zgodne, że istota Boga (Al-Dhat, ousia) jest dla człowieka niepoznawalna i charakteryzuje się „całkowitą innością” w stosunku do tego, co człowiek zna. Bóg posiada jednak swoje atrybuty, aktywności lub imiona (Al-Asma al-Husna) powiedzą sufi lub energie, moce, łaskę (energeiai) powiedzą hezychaści. Wydaje się, że pojęcia te można ze sobą zrównać, tym bardziej, że teza o tożsamości energii bożych i Imienia Bożego jest również obecna w Kościele Prawosławnym (imiesławie). Poprzez swoje imiona i ich sens Bóg objawia się światu, dlatego „zakochany”, tj. mistyk, powinien za nimi podążać, powiadał Ibn Arabi (1165-1240) [Ibn Arabi 1995: 129].

Rumi (1207-1273), najwybitniejszy poeta suficki, dystynkcję pomiędzy Bogiem i jego aktywnościami wyraził w koncepcji formy i znaczenia. Formę stanowił dla niego świat, a znaczenie ukryta realność, którą zna Bóg. Forma i znaczenie były ze sobą nierozerwalnie związane, forma pochodziła ze znaczenia, a znaczenie manifestowało się w formie [Chittick 1983: 24]. Można więc powiedzieć, że to dwie strony tej samej rzeczywistości, jej fenomen i noumen.

Tradycja chrześcijańska i islamska zgodnie wskazują na wolę Boga do objawienia się człowiekowi. Mistycy islamscy, przede wszystkim Ibn Arabi w Traktacie o mitości, cytując słowa tradycji: „Byłem ukrytym skarbem, nikt mnie nie znał i zapragnąłem, by mnie poznano. Powołałem więc do życia stworzenia i dałem się im poznać, by mnie poznały" dowodzi, że Bóg stworzył świat aby dać się poznać, zamanifestować swoje istnienie człowiekowi z miłości do niego. Podobne tezy odnajdujemy w Obronie szczegótowej Grzegorza Palamasa, gdzie czytamy, że Bóg jest „działający i chcący”. Cecha „chcenia” wskazuje na wolę Boga, a ,działania” na jego energię [Palamas 2010: 131]. Za pośrednictwem energii Bóg objawia wolę własnej manifestacji światu. 
Istota Boga, pomimo tego, że jest różna od jego atrybutów czy manifestacji, to zawiera się w nich i w tym kontekście jest częściowo poznawalna, ale w sposób szczególny - intuicyjnie. Człowiek jest w stanie zbliżać się więc do poznania Boga, obrazowo proces ten zilustrować można jako drabinę wstępowania ku Bogu. W hezychazmie koncepcję wstępowania, przedstawił w VII w. Jan Klimak w pracy Drabina Raju. Święty z Synaju wyróżnił trzydzieści stopni i trzy poziomy wstępowania ku Bogu. Pierwszy poziom sprowadza się do porzucenia świata zewnętrznego i pogrążenie się w świat duchowy, drugi poziom stanowi praksis aktywną walkę z wadami i praktyką cnót. Trzeci poziom, najważniejszy, to theoria czyli życie kontemplacyjne, pokój duszy i zjednoczenie z Bogiem, tj. przebóstwienie. W nauczaniu sufich, według Williama Chitticka, również wyróżniamy trzy filary, które organizują całe ich przesłanie: pierwsze dwa filary można odnieść do wiedzy i pracy, mądrości i metody lub też teorii i praktyki. Trzeci filar stanowi duchowa realizacji, dotarcie do Boga [Chittick 1983: 10-11]. Powodzenie praktyk mistycznych uzależnione jest więc od zdyscyplinowanej i systematycznej pracy nad umysłem, sercem i ciałem. Ich celem jest deifikacja (theosis) w przypadku hezychastów lub anihilacja, rozpłynięcie własnego ,ja”, zapomnienie, samozniszczenie, samozaprzeczenie (fana) w przypadku sufich. Rumi scharakteryzował ten proces $\mathrm{w}$ następujących słowach: „w uszczuplaniu siebie, o szlachetny przyjacielu, znajdziesz prawo religijne nad prawa religijne, gramatykę nad gramatyką i fleksję nad fleksją" [Rumi 2009: 56]. Jednak nawet wtedy, na samym szczycie drabiny duchowej, człowiek nie jest w stanie objąć całości Boga, jego istota nadal pozostaje niewyrażalna i niepoznawalna.

Mistyczne przeobrażenie człowieka odbywa się dzięki miłości i woli Boga: „[p] oczątkiem i przyczyną przebóstwionych jest Bóg [...]”, powiadał Palamas [Palamas 2010: 147]. Miłość to słowo, które ma wiele znaczeń. Ibn Arabi wyróżnił trzy rodzaje miłości. Pierwszy rodzaj dotyczy miłości, jaką odczuwają wszystkie stworzenia i wynika ona z miłości do nich Boga (mahabba; hubb ilahi), wyraża się „poprzez wskazówki, jakich nam udziela, nakazując jak postępować, by osiągnąć szczęście i tym samym jak uniknąć czynów niezgodnych z naszą naturą i rodzajem" [Ibn Arabi 1995: 32; Koran 2: 165; 3: 31; 5: 54]. Drugi rodzaj miłości - miłość wiernych i pewnych - rodzi się w sercach ludzi jako rezultat uwielbienia dla majestatu Boga, jego wielkości, wiedzy i mocy. I wreszcie trzeci rodzaj miłości - miłość wtajemniczonych - powstaje dzięki ich wiedzy o miłości [Wronecka 1995: XXXVI]. W chrześcijaństwie z kolei mamy do czynienia z dwoma rodzajami miłości: 1) philein, co oznacza miłość przyjacielską oraz 2) agapan, miłość intelektualną. Philos określa kogoś bliskiego, z kim związani jesteśmy miłością i wiernością. W czasach chrześcijańskich, w Nowym Testamencie, słowo to nabrało nowych cech, zaczęło charakteryzować „chrześcijańskie stosunki miłości”. Utożsamiano je niekiedy z agapan w przypadku gdy mowa była o przykazaniu miłości. Czasownik agapan rozumiany jako "miłować” charakteryzuje uczucie boskie i absolutne, a nie ludzkie 
i warunkowe, świadczy o braterstwie Boga i człowieka, oznacza miłość uniwersalną [Kroczak 2015: 140-141]. Miłość stanowi więc najważniejsze narzędzie i środek realizacji praktyk ascetycznych i mistycznych.

Hezychaści i sufi nieustannie przekonują o roli serca w kształtowaniu się życia ascety. Według nich serce (kardia; dil, qalb) jest centrum ludzkiej świadomości, jego największą realnością. Makary Wielki w Homiliach duchowych powiadał, że: „serce rządzi całym ludzkim organizmem i kiedy łaska zawładnie prawami serca, ono włada wszystkimi myślami i członkami człowieka. Dlatego umysł i wszystkie myśli duszy są tam umiejscowione [tj. w sercu]" [Makary Egipski 1865: col. 589B]. W sercu musi zagościć oprócz miłości również spokój. Serce powinno zostać bezwzględnie oczyszczone ze wszystkiego co nie jest Bogiem, według Al-Ghazaliego, stanowi to klucz gwarantujący powodzenie modlitwy adorującej [al-Ghazali 2008: 168]. Jan Klimak z kolei twierdzil, że zapewnia to pamięć o Jezusie, tj. wypowiadanie krótkiej modlitwy „panie Jezu Chryste, Synu Boży zmiłuj się nade mną", lub po prostu imienia Jezus. Bardziej zaawansowana praktyka polegała na powtarzaniu tej formuly we własnym sercu bez użycia słów, co miało na celu nieustanną pamięć o Jezusie i wyciszenie (hesychia).

Kwestię tę rozwija także Al-Sarraj (um. ok. 988 r.), który w Księdze blasku uchodzącej za podręcznik wiedzy o sufizmie pisał, że wewnętrzny spokój (sakina) osiąga się poprzez kontemplację, oczyszczenie i wspominanie Boga, tj. rytualne powtarzanie krótkiej frazy (szahady) w brzmieniu: „Nie ma Boga jak tylko Allah" lub wymienianie imion Allaha. Należy dążyć do tego, aby frazy te powtarzać niewerbalnie, w umyśle, ponieważ jak powiadał Rumi: „kto pozna tajemnicę percepcji musi zasznurować usta” [Shah 2009: 97]. Czynności te wiodą do mistycznego odczytania Koranu.

Muhammad ibn Salim, sufi żyjący w X w., wyróżnił trzy rodzaje wspomnienia o Bogu: za pomocą 1) języka, 2) serca oraz 3) wspominanie, które definiuje się jako bycie wypełnionym miłością i wstydem z powodu bliskości Boga - wspominanie to powoduje zanikanie ludzkiej natury (bashariyyat) [al-Sarraj 1914: 61; Koran 33: 43]. Dzięki dhikr spełnia się cel uniwersalnego objawienia, człowiek pozostaje w związku ze sferą niebieską, powiadał Ibn Arabi, jeden z najwybitniejszych arabskich metafizyków [Ibn Arabi 1995: 150].

Uważa się, że dhikr był jedną z kluczowych praktyk muzułmańskich od samego początku, ponieważ implikował oddawanie czci Bogu, co w konsekwencji prowadziło do powrotu do niego na każdym poziomie bytu. Zachęta do dhikr Allah pojawia się w Koranie dwadzieścia sześć razy. Praktyka ta nie stała się jednak masowa ponieważ odnosi się do sfery kontemplacji, a nie rytuału [Chittick 2012: 92-95]. W przypadku modlitwy Jezusowej i hezychii sytuacja jest podobna - z racji swojej dyscypliny duchowej nie zyskały masowej popularności.

W tradycji hezychastycznej, w sposób systematyzujący, kwestia wspominania Boga w sercu została podjęta w Filokalii, gdzie zgromadzono teksty pisarzy wczesnochrześcijańskich i Ojców Kościoła poświęconych modlitwie Jezusowej. 
Sergiusz Bułgakow, rosyjski filozof religijny pisał, że zgodnie z tradycją i nauką wielkich mistrzów życia duchowego, modlitwa Jezusowa ma trzy stopnie. Pierwszy to modlitwa ustna, początkujący asceta musi dokonać wysiłku, aby w umyśle i na ustach mieć nieustannie modlitwę Jezusową, to tzw. modlitwa ustna. Kolejnym krokiem jest modlitwa duchowa lub rozumowa. Asceta koncentruje się na imieniu Jezusa, które objawia ukrytą w sobie moc Chrystusa. Na tym stopniu jest już odczuwalna moc imienia Jezusowego. Ostatnim etapem jest osiągnięcie takiego stanu, kiedy modlitwa odmawiana jest wyłącznie w duchu lub w sercu, czyli modlitwa serca, kiedy święte imię przenika wewnętrzną naturę człowieka. Rozróżnienie tych trzech etapów modlitwy jest orientacyjnym schematem, który ukazuje możliwą ścieżkę duchowego rozwoju człowieka, ale stanowi jednocześnie ostateczne ukoronowanie wszystkich praktyk ascetycznych [Bulgakow 1992: 164].

Modlitwa serca ufundowana została na ewangelicznym poleceniu Jezusa: „zawsze należy się modlić i nie ustawać” (Łk 18,1), powtórzył to św. Paweł w liście do Tesaloniczan: „nieustannie się módlcie” (1Tes 5,17). Taką formę modlitwy, którą można porównać do „wewnętrznej medytacji” (krypte melete) rozwinęli już Ojcowie pustyni w IV w. [Naumowicz 2002: 22-23]. O „wewnętrznej medytacji” mówią również sufi, określają ją mianem fikr, polega ona na pamiętaniu i inwokacji do Boga [Chittick 1983: 160].

W okresie schyłkowego Bizancjum, w XIV w., kiedy tradycja hezychastyczna została usystematyzowana, ożywa tendencja (znana od czasów Jana Klimaka), aby części modlitwy łączyć z wdechem i wydechem, pierwszą część „Panie Jezu Chryste, Synu Boży” wymawiać podczas wdechu, drugą zaś: „zmiłuj się nade mną grzesznym” w czasie wydechu. Zaleca to m.in. Grzegorz z Synaju. W 1330 r. ten bizantyjski anachoreta założył w południowo-wschodniej Bułgarii, w górach Strandża klasztor, z którego, obok Athosu, oddziaływała na kulturę ruską ideologia hezychastyczna. Uczniem św. Grzegorza był św. Teodozjusz z Tyrnowa (1300-1363), a jego z kolei św. Eutymiusz, który uciekając z Tyrnowa podbitego przez sułtana osmańskiego Bajazyda I pod koniec XIV w. schronił się na Rusi, m.in. inicjując tam „renesans hezychazmu”.

Modlitwa Jezusowa i hezychia podobnie jak dhikr nie były rodzajami typowej medytacji. Należałoby je rozumieć raczej jako świadomość Boga, pamięć o nim, „absolutną koncentrację" na Bogu [Chittick 2012: 90]. Pierwszy stopień procesu stanowi zapomnienie o własnym ,ja” a ostatni zlanie się w jedno przedmiotu i podmiotu, „rozpłynięcie się” w Bogu.

Istnieje jednak ważna różnica między dhikr i hezychia, sprowadza się ona do tego, że pamięć o Bogu w sufizmie będzie przede wszystkim wspominaniem jego „jedyności” i niepodzielności, ponieważ centrum koncepcji dhikr Allah znajduje się w muzułmańskiej idei tawhid wyrażającej naturę realności, „niezależność istnienia uniwersum, człowieka i każdego innego bytu" [Chittick 2002: 49]. W hezychazmie natomiast chodzi o żal za grzechy i prośbę o zmiłowanie. Co więcej 
Bóg chrześcijański jest „nie-jednością, z powodu swej wyższości, jest On bowiem ponad jednością i określa tę jedność”, pisał Palamas [Palamas 2010: 130]. Hezychaści i sufi pragną, poza rzeczywistością werbalną znaleźć Boga, ale w czasie modlitwy asceci chrześcijańscy spotykają się z Bogoczłowiekiem Jezusem, drugą osobą Trójcy św., a muzułmańscy z Bogiem, którego cechą niezbywalną jest jedyność (tawhid).

Hezychazm i sufizm odwodzą wierzących od świata materialnego i skłaniają do życia kontemplacyjnego: „Każdy, kto pragnie duchowego zdrowia, porzuca ten świat" [Rumi 2009: 121]. Ich celem jest więc osobiste doświadczenie Boga, a nawet częściowe zjednoczenie z nim, w procesie tym rolę podstawową spełnia serce, „duchowe centrum człowieka”. Asceci suficcy i hezychaści zwróceni są ku wnętrzu, ale nie negują ciała, dopuszczają nawet uświęcenie ciała. Sufi, w odróżnieniu od hezychastów, uświęcają nawet „cielesność” i nie wyrzekają się świata, stoją więc częściowo w opozycji to prądów mistycznych bazujących na platonizmie. Częściowo, ponieważ pojawia się u nich także wiele wątków platońskich. Paweł Florenski, rosyjski filozof religijny uważał, że platońska formula hen kai pan (jedność w wielości) oznaczała, że w zjawiskach przejawia się istota, co stanowi uogólnioną koncepcję palamizmu [Kroczak 2015: 163]. U sufich z kolei pojawia się metafora zasłony oddzielającej ich od Boga, otaczające człowieka rzeczy to odbicie idei Boga [al-Ghazali 1990: 56-67]. Świat stanowi więc nie-byt, iluzję, platońską jaskinię.

Niektórzy badacze uważają, że sufizm był spadkobiercą chrześcijańskiej tradycji ascezy. Muzułmanie spotykali bowiem arabskich chrześcijan (monofizytów i nestorian) w Mezopotamii i Syrii, obserwowali ich metody modlitwy: recytację psalmów i pokłony - wywoływało to na nich duże wrażenie [Cook 2007: 115; Bielawski 1986: 762]. Z drugiej strony, Idries Shah, znany nauczyciel sufizmu, wskazywal, że chrześcijaństwo również nie pozostało obojętne na wpływy sufizmu. Twierdził, że sufickie idee, a nawet konkretne teksty, zostały wykorzystane lub legły u podłoża tak zróżnicowanych teorii, organizacji i indywidualnych systemów, m.in. rycerstwo, mistyka św. Jan od Krzyża i św. Teresa z Avila oraz filozofia Rogera Bacona [Shah 2009: 17]. Autor ten nie wskazuje jednak żadnych tekstów ani postaci z tradycji prawosławnej.

Między sufizmem a hezychazmem istnieją jednak zasadnicze różnice, o niektórych była mowa w toku artykułu, m.in. o statusie Jezusa czy jedności Boga. Warto również zauważyć, że hezychazm nie korzysta z poezji, prozy, muzyki, tańca i śpiewu jako środków wyrażenia emocji i praktyk religijnych. Hezychazm nie propaguje koncepcji Boga immanentnego, natomiast w sufizmie często spotykamy tezy, takie jak ta autorstwa Dżunajda (um. 910): „wszystko, co odnosi się do Prawdziwego Bytu jest pochłonięte przez Boga i staje się Bogiem”, czy Al-Halladża (um. 922): "Jestem Bogiem, jestem Prawdą" [Miller 1986]. Geo Widengren twierdził nawet, że sufizm (szczególnie jego perska odmiana) okazuje się być czystym panteizmem monistycznym, w którym Bóg jest treścią świata [Widengren 2008: 523-525]. Znajduje się on w każdej cząstce rzeczywistości i w samym człowieku. 
Co ważne, hezychazm stanowi zjawisko bardziej jednolite niż sufizm. Tradycja hezychastyczna jest spójna, zgodna z oficjalnym prawosławiem, natomiast status sufizmu w islamie nie jest jednoznaczny. Sufi wykorzystują elementy ludowe, innych religii, a nawet elementy pogańskie do swych nauk, co w sposób naturalny nie może zostać zaakceptowane przez oficjalną teologię islamską. W ramach sufizmu możemy mówić o jego odmianie w poezji, prozie, sztuce, filozofii. Zakres wpływu nauki hezychastycznej jest nieco mniejszy, wplynęla ona głównie na filozofię (rosyjski renesans religijno-filozoficzny) i malarstwo (Andriej Rublow, Teofan Grek).

Hezychazm i sufizm we wszystkich swych odmianach chcą widzieć i interpretować naturę człowieka w jego relacji do Boga. Człowiek to istota integralna, która posiada możliwość przekraczania swej kondycji i właśnie na tym procesie transcendowania zasadza się jej rozwój. Antropologie sufizmu i hezychazmu postulują wyjątkowe miejsce i rolę człowieka we wszechświecie, sprowadza się ona do zrozumienia i odczucia idei ,jedności w wielości” czyli duchowej „całościowości” rzeczywistości poprzez jego materialną antynomiczność. Wspominany już Florenski, współczesny rosyjski hezychasta pisał: „[a]ntynomiczność jest rękojmią całościowości, czyli idei, czyli nadzmysłowości. Na odwrót, prosta jedność świadczy o niepełności, empiryczności i niecałościowości zjawiska. W tym sensie można powiedzieć, że bieguny to początek i koniec przejawiania się tego, co nadzmysłowe, w sferze tego, co zmysłowe, miejsce wejścia i wyjścia IDEI w świat empiryczny" [Florenski 2009: 176]. Ideą tą jest Bóg, który przejawia się w świecie w postaci swych atrybutów i wytworów. Zadaniem człowieka jest je dostrzec i kontemplować.

\section{LITERATURA}

[al-Ghazali 1990] - Al-Ghazali, Nisza świateł, przel. J. Wronecka, PWN, Warszawa.

[al-Ghazali 2008] - Abu Hamid al-Ghazali, Ratunek przed zbtadzeniem, przeł. K. Pachniak, Wydawnictwo Akademickie Dialog, Warszawa.

[al-Sarraj 1914] - Abu Nasr Abdallah B. Ali Al-Sarraj Al-Tusi, The Kitáb al-Luma fi l'tasawwuf, ed. R. Nicholson, Luzac \& Co., London.

[Bielawski 1986] - J. Bielawski, Wprowadzenie, [w:] Koran, przeł. J. Bielawski, PWN, Warszawa.

[Bułgakow 1992] - S. Bułgakow, Prawostawie, przel. H. Paprocki, Orthdruk, Białystok.

[Chittick 1983] - W. C. Chittick, The spiritual path of love. The spiritual teaching of Rumi, State University of New York Press, New York.

[Chittick 2002] - W. Chittick, The cosmology of dhikr, [w:] Path to the Heart: Sufism and the Christian East, ed. J. Cutsinger, World Wisdom/Fons Vitae, Bloomington.

[Chittick 2012] - У. Читтик, Суфизм. Руководство дıя начинающего, пер. М. Г. Романов, Я. Эшотс, Издательская фирма «Восточная митература», Москва.

[Chittick, Rustom, Khalil 2012] - W. C. Chittick, M. Rustom, A. Khalil, In Search of the Lost Heart: Explorations in Islamic Thought, State University of New York Press, New York. 
[Choruży 2014] - S. Choruży, Hezychazm i kultura, przeł. Ł. Leonkiewicz, „Elpis”, nr 6. [Cook 1986] - D. Cook, Męczeństwo w islamie, przeł. Ł. Muller, Wydawnictwo Uniwersytetu Jagiellońskiego, Kraków.

[Cook 2007] - D. Cook, Męczeństwo w islamie, przel. Ł. Muller, Wydawnictwo Uniwersytetu Jagiellońskiego, Kraków.

[Fakhry 2004] - M. Fakhry, A history of Islamic philosophy, Columbia University Press, New York.

[Florenski 2009] - P. Florenski, Divina sive aurea sectio. Ztoty podziat, przeł. B. Strachowski, [w: tenże, Sens idealizmu, IFiS PAN, Warszawa.

[Gentili 1997] - A. Gentili, Chrześcijaństwo i ezoteryzm, przeł. A. Wieczorek, Wydawnictwo WAM, Kraków.

[Ibn Arabi 1995] - Ibn Arabi, Traktat o miłości, przeł. J. Wronecka, PWN, Warszawa.

[Jan z Damaszku 2011] - Jan z Damaszku, Dialektyka albo Rozdziaty filozoficzne. O herezjach, Wydawnictwo WAM, Kraków.

[Kokkinos 1865] - Ph. Kokkinos, Encomnium Gregorii Palamae, PG 151.

[Kroczak 2015] - J. Kroczak, Pawła Florenskiego filozofia wszechjedności, IFiS PAN, Warszawa.

[Łosski 2007] - W. Łosski, Teologia mistyczna Kościoła Wschodniego, przeł. I. Brzeska, Wydawnictwo Uniwersytetu Jagiellońskiego, Kraków.

[Makary Egipski 1865] - Pseudo-Makary Egipski, Homilie Duchowe XV, PG 34.

[Miller 1986] - E. Miller, Sufis: the mystical muslims, http://www.equip.org/article/sufis-the-mystical-muslims/ (20.01.2016).

[Naumowicz 2002] - J. Naumowicz, Wstęp, [w:] Filokalia. Teksty o modlitwie serca, przel. J. Naumowicz, Wydawnictwo M, Kraków.

[Opis podróży Makarego 1898] - Путешествие Патриарха Макария, пер. Г. Муркос, Университетская типографія, Страстной бульваръ, Москва.

[Palamas 1865] - G. Palamæ, De Hesychastis, PG 150.

[Palamas 2010] - G. Palamas, Obrona szczegótowa, [w:] Palamas, Bułgakow, Łosiew, red. L. Kiejzik, Wydawnictwo Naukowe Scholar, Warszawa.

[Rumi 2009] - D. Rumi, Anioł upojny. Opowieści mistyczne, przeł. I. Nowicka, Wydawnictwo Akademickie Dialog, Warszawa.

[Shah 2009] - I. Shah, Droga Sufich, przeł. T. Bieroń, Zysk i S-ka, Poznań.

[Shahid 2007] - I. Shahid, Byzantium and the Islamic World, [w:] Byzantium and the Islamic World. Byzantium a world civilization, eds. A. E. Laiou, H. Maguire, Dumbarton Oaks, Washington D.C.

[The lives of the pillars 1990] - The lives of the pillars of orthodoxy, compilation by Holy Apostole convent, Buena Vista, Colorado.

[Tomkowski 2006] -J. Tomkowski, Mistyka i Herezja, Wydawnictwo Dom na Wsi, Ossa.

[Widengren 2008] - G. Widengren, Fenomenologia religii, przeł. J. Białek, Nomos, Kraków.

[Wronecka 1995] - J. Wronecka, Wstęp, [w:] Ibn Arabi, Traktat o mitości, przel. J. Wronecka, PWN, Warszawa.

[Бранчанинов 2007] - Писвма свлтителя Игнатия в ответ соблазняющимся на «Слово о Смерти», [w:] Полное собрание творений Святителя Игнатия Бранчанинова, т. VIII, Памомник, Москва 2007. 
Justyna Kroczak

\title{
THE MYSTICAL HUMAN DEVELOPMENT ON THE EXAMPLE OF HESYCHASM AND SUFISM
}

\begin{abstract}
(Summary)
Mysticism understood as an experience of manifestation of God's mystery is an integral part of any religion. In Christianity, a Hesychastic spirituality begun to form in $4^{\text {th }}$ century. It reached its summit in the theology of St. Gregory Palamas. Sufism, in turn, combines elements of popular piety, koranic law and tradition. In $12^{\text {th }}$ century the Sufi doctrine was formalized in the teaching of Ibn Arabi and Jalaluddin Rumi. However, there are many similarities in the structure, elements and goals of the Sufi and Hesychastic religious practices. The article is an attempt at a comparative analysis of the two paths of spiritual development with an emphasis on the views and possible impacts of their main representatives.
\end{abstract}

